\section{Psychological impairment and low-dose benzodiazepine treatment}

It is generally accepted that excessive use of benzodiazepines may lead to physical dependence and a withdrawal syndrome, but recently it has been reported that prolonged use of doses within the normally accepted therapeutic range may lead not only to a withdrawal reaction but also to some psychological impairment during treatment. ${ }^{12}$ This conclusion, drawn from studies on coding ability as represented by digit symbol substitution, is, however, hard to accept. The authors observed an improvement in performance during testing, but this occurred before the drug was even partially withdrawn, one group studied remained on full dose for four weeks. Furthermore, both groups experienced similar improvements even though withdrawal was delayed by two weeks in one, and, as judged from the data, the absolute level of performance of this group remained higher throughout the period of testing. These observations, together with the absence of a control group to establish the pattern of learning over a period of 10 weeks, suggest that increased familiarity with the test could not be excluded as the reason for the improvement in performance.

In view of the conclusion reached by Petursson and Lader and of its possible clinical significance we have studied the performance of 10 healthy volunteers on digit symbol substitution.

\section{Subjects, methods, and results}

We studied the performance of 10 healthy volunteers (eight men and two women) aged 24-50 years on digit symbol substitution over a period of 10 weeks, and analysed the data with an analysis of variance. The subjects were not familiar with the test, which was carried out as described by Petursson and Lader. ${ }^{2}$

The mean number of substitutions over the first and second weeks was $44.8\left(\mathrm{SEM}_{ \pm} \pm 3.55\right)$. The score increased over the study period, particularly over the first four weeks with sharp increases between weeks 1 and 2 and between weeks 2 and $4(p<0.01)$. During the last six weeks improvement was less pronounced, but even so scores during the eighth and ninth weeks were higher $(p<0.05)$ than those of any of the first four weeks, and scores during the 10th week were higher than those of any of the first six weeks (see figure). Substitutions over the last four weeks averaged $16 \cdot 6$ above the mean of the first two weeks.

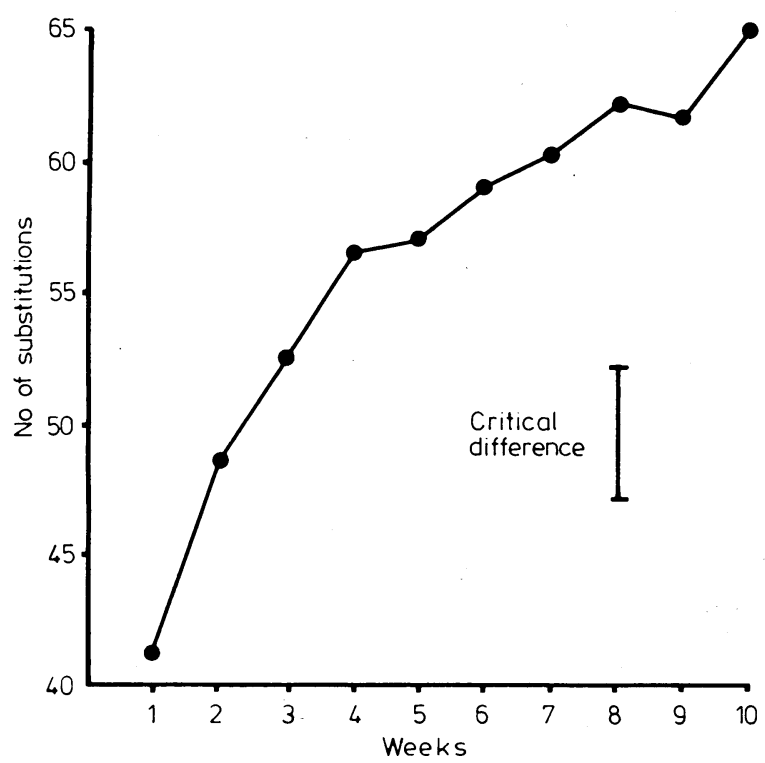

Digit symbol substitution test: change in number of substitutions within 90 seconds over 10 weeks (mean for 10 subjects). Critical difference $(5 \cdot 05)$ was obtained using Tukey's method based on the Studentised range and indicates value at which difference between weeks is significant $(p<0.05)$.

These changes are similar to those of the two groups of Petursson and Lader, ${ }^{2}$ which also showed a pronounced increase in substitutions over the first four weeks and a slower but continued improvement thereafter. The mean scores over the first two weeks were $46 \cdot 0\left(\mathrm{SEM}_{ \pm 3} \cdot 7\right)$ and $49 \cdot 9$ $\left(\mathrm{SEM}_{ \pm 2} \cdot 9\right)$, and, as judged from their data, the mean for each group over the last four weeks was about 15 substitutions above the mean of the first two weeks. Initial scores for the patients diagnosed as having psychiatric problems and for the healthy volunteers were similar, and so there was no evidence that the patients were impaired when they were first introduced to the test.

\section{Comment}

Though behavioural effects during withdrawal from low doses of benzodiazepines may be related to the previous use of the drug, the data presented by Petursson and Lader do not suggest that psychological impairment is associated with prolonged use of low doses of benzodiazepines. Indeed, the improvement in performance they observed during withdrawal may be explained by learning alone, and the rate of improvement was at all times similar to that of healthy individuals. An alternative interpretation of the dat $\mathfrak{i}$ is that the prolonged use of low doses of benzodiazepines is unlikely to lead to psychological impairment even in those patients who may exhibit some dependency as indicated by a reaction on withdrawal of the drug.

${ }^{1}$ Petursson $\mathrm{H}$, Lader MH. Withdrawal reaction from clobazam. $\mathrm{Br} \mathrm{Med} \mathcal{F}$ $1981 ; 282: 1931$.

${ }^{2}$ Petursson $\mathrm{H}$, Lader MH. Withdrawal from long-term benzodiazepine treatment. Br Med f $1981 ; 283: 643-5$.

(Accepted 28 April 1982)

Royal Air Force Institute of Aviation Medicine, Farnborough, Hants A N NICHOLSON, DSC, FRCPATH, consultant in aviation medicine M B SPENCER, BA, MSC, senior scientific officer (statistics)

\section{Multiple general anaesthesia with Althesin}

Despite extensive research and trials of other treatment surgery remains the treatment of choice for juvenile papillomatosis. Patients with severe disease often require a fairly rigid programme of repeated, scrupulous removal to control the papillomata. We describe a patient with papillomatosis treated by microlaryngoscopy and suction diathermy in whom Althesin proved to be an excellent anaesthetic supplemented with nitrous oxide and oxygen.

\section{Case report}

The patient, a 19-year-old woman, first presented at the age of 6 with a short history of difficulty with respiration. Laryngeal papillomatosis affecting the entire larynx was diagnosed at endoscopy. The airway problem necessitated a tracheostomy, which has re.nained to the present day. The disease was partially controlled for the next nine years by repeated endoscopic removal using cup forceps, but her condition gradually deteriorated, with papillomata progressively extending distally to affect the trachea and bronchi.

A series of suction diathermy procedures began when the patient was 15 , since when 84 anaesthetics were administered at intervals of one to four weeks.

Method of anaesthesia-To reduce recovery time premedication was with atropine only. Althesin was given intravenously in a dose of $2-4 \mathrm{ml}$, through an indwelling butterfly needle, followed by $12 \mathrm{mg}$ of Flaxedil (gallamine triethiodide) and $20-50 \mathrm{mg}$ of suxamethonium. A James's trackeostomy tube was inserted. The lungs were inflated with oxygen and the larynx and trachea were sprayed with $5 \mathrm{ml}$ of $4 \%$ xylocaine. During suction diathermy of the larynx the lungs were ventilated manually with $50 \%$ nitrous oxide and $50 \%$ oxygen. Incremental doses of Althesin $(1 \mathrm{ml})$ and suxamethonium $(25 \mathrm{mg}$ ) were given when necessary. The procedures usually lasted between 10 and 15 minutes.

The total dose of Althesin never exceeded $10 \mathrm{ml}$ and the patient recovered consciousness in three to five minutes. There was no postoperative discomfort and no nausea or vomiting.

\section{Comment}

Adverse reactions have been reported with Althesin (alphadolone and alphaxolone in polyoxyethylated castor oil; Glaxo), though the incidence quoted differs considerably. ${ }^{12}$ Commonly reported reactions are those showing features of histamine release ("histaminoid" reactions), bronchospasm, cardiovascular effects, and involuntary muscle movements. 
In nearly 14000 administrations of Althesin the senior author of this paper $(R L)$ has seen only two severe adverse reactions. These were in children of 5 and 6 years old after a second maxillary antral washout for chronic sinusitis within three weeks. The reaction occurred immediately and was manifested by pronounced pallor and cardiovascular collapse with pronounced tachycardia but no bronchospasm. Both cases responded satisfactorily to intravenous administration of chlorpheniramine and hydrocortisone and ventilation with oxygen. Administering Althesin to other patients, we have observed a very low incidence of minor reactions such as flushing of the neck and shoulder region, coughing, hiccups, and limb movements. The patient discussed here, however, showed no adverse reactions, either of hypersensitivity or of untoward movement or coughing (obviously particularly important during a microlaryngoscopic procedure). The patient had the endoscopic procedures performed on a day-case basis without anatgesia. Throughout this time she has continued full schooling and is now at university. Althesin has been shown to be rapidly cleared from the plasma in animals and subsequently eliminated. ${ }^{3}$ Clinical events in this case suggest that this is so in man and makes Althesin a good choice where repeated general anaesthetics may be necessary.

We thank Mr R Pracy for his permission to report this case.

${ }^{1}$ Clarke RSJ, Dunde JW, Garrett RT, McArdle GK, Sutton JA. Adverse reactions to intravenous anaesthetics. A survey of 100 reports. $\mathrm{Br} \mathcal{F}$ Anaesth 1975; 47:575-85.

2 Evans JN, Keogh JAM. Adverse reactions to intravenous anaesthetic induction agents. $\mathrm{Br}$ Med $\mathcal{F} 1977$; $\mathrm{ii}: 735-6$.

3 Child KJ, Gibson W, Harnby G, Hart JW. Metabolism and excretion of Althesin (CT 1341) in the rat. Postgrad Med F 1972;48, suppl 2:37.

(Accepted 16 April 1982)

Royal National Throat, Nose, and Ear Hospital, London WC1X 8DA DAVID J HOWARD, FRCS, FRCSED, senior surgical registrar, professorial unit

SUSAN FARAG, DA, FFARCS, anaesthetic registrar

ROBERT M LISCOMBE, FFARCs, consultant anaesthetist

\section{Acute renal failure and rise in alkaline phosphatase activity caused by cimetidine}

Acute renal failure caused by cimetidine is rare. ${ }^{12}$ There are no reports of renal failure confirmed by a second exposure to the drug. Hepatotoxicity is also uncommon and is usually confined to a rise in serum transaminase activities. ${ }^{3}$ We describe a patient treated twice with cimetidine who developed acute renal failure and considerable rise in alkaline phosphatase activity on both occasions.

\section{Case report}

A 67-year-old man developed haematemesis and melaena in July 1980 . A barium meal examination at another hospital showed a duodenal ulcer and he was treated with cimetidine $1 \mathrm{~g}$ daily. His haemoglobin concentration was $11.7 \mathrm{~g} / \mathrm{dl}$, sodium $135 \mathrm{mmol}(\mathrm{mEq}) / \mathrm{l}$, urea $5.1 \mathrm{mmol} / 1(31 \mathrm{mg} / 100 \mathrm{ml})$ creatinine $100 \mu \mathrm{mol} / 1(1.1 \mathrm{mg} / 100 \mathrm{ml})$; and alkaline phosphatase $90 \mathrm{IU} / \mathrm{l}$ (13 KA units). Two months later he complained of excessive sweating and feeling faint. His haemoglobin was now $8.5 \mathrm{~g} / \mathrm{dl}$, sodium $123 \mathrm{mmol} / 1$, urea $19 \mathrm{mmol} / 1$ (114 mg/100 ml), creatinine $550 \mu \mathrm{mol} / 1(6.2 \mathrm{mg} / 100 \mathrm{ml})$, and alkaline phosphatase 700 IU/1 (99 KA units). Drug toxicity was suspected and his medication was discontinued. He was treated with intravenous saline and recovered uneventfully. Six weeks later his haemoglobin was $11.9 \mathrm{~g} / \mathrm{dl}$, sodium $137 \mathrm{mmol} / 1$, urea $7.6 \mathrm{mmol} / 1(46 \mathrm{mg} / 100 \mathrm{ml})$, creatinine $150 \mu \mathrm{mol} / \mathrm{l}$ $(1.7 \mathrm{mg} / 100 \mathrm{ml})$, and alkaline phosphatase $87 \mathrm{IU} / 1$ (12 KA units). Endoscopy showed duodenitis but no ulcer.

In October 1981 he complained of upper abdominal pain. A further endoscopy showed a duodenal ulcer and he was treated with cimetidine $1 \mathrm{~g}$ daily. At this time his haemoglobin was $9 \cdot 7 \mathrm{~g} / \mathrm{dl}$, urea $8.6 \mathrm{mmol} / 1(52 \mathrm{mg} / 100$ $\mathrm{ml})$, creatinine $160 \mu \mathrm{mol} / 1(1.8 \mathrm{mg} / 100 \mathrm{ml})$, and alkaline phosphatase $69 \mathrm{IU} /$ (10 KA units). Three days later he was admitted urgently under our care complaining of excessive sweating and malaise. He attributed his symptoms to cimetidine. His haemoglobin was $8.7 \mathrm{~g} / \mathrm{dl}$; urea $10.2 \mathrm{mmol} / \mathrm{l}(61 \mathrm{mg} / 100$ $\mathrm{ml})$, creatinine $260 \mu \mathrm{mol} / 1(2.9 \mathrm{mg} / 100 \mathrm{ml})$, and alkaline phosphatase 74 IU/1 (10 KA units). Over the next 11 days he developed high fever and progressive renal failure associated with pronounced rise of alkaline phosphatase. Blood urea rose to $40.7 \mathrm{mmol} / 1(244 \mathrm{mg} / 100 \mathrm{ml})$, creatinine to $1450 \mu \mathrm{mol} / 1(16.4 \mathrm{mg} /$ $100 \mathrm{ml}$ ), and alkaline phosphatase to $1165 \mathrm{IU} / 1$ (163 KA units). He had no rash, arthralgia, or peripheral blood eosinophilia. Cimetidine was discontinued. Three days later diuresis occurred with reversal of the biochemical abnormalities. After further gastrointestinal bleeding, vagotomy and pyloroplasty was performed on 18 January 1982 . A renal biopsy specimen taken at operation showed a focal interstitial inflammatory cell infiltrate, consisting mainly of lymphocytes and plasma cells, with associated atrophy of adjacent tubules; elsewhere the tubules appeared normal (figure). The results of

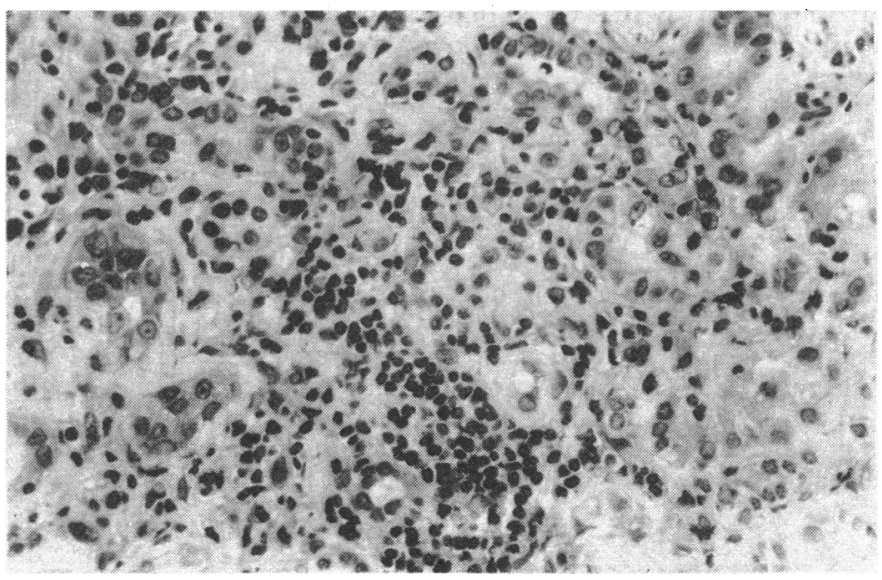

Histological findings on renal biopsy. Martius scarlet blue, plastic embedded section. $\times 600$ (original magnification).

immunofluorescence tests for IgA, IgM, Clq, C3, and fibrinogen were negative. IgG was present focally in the interstitium in relation to plasma cells. These appearances were consistent with a resolving interstitial nephritis. When discharged 10 days later his blood urea was $5.6 \mathrm{mmol} / 1$ (33.6 mg/100 $\mathrm{ml})$, creatinine $180 \mu \mathrm{mol} / \mathrm{l}(2.0 \mathrm{mg} / 100 \mathrm{ml})$, alkaline phosphatase $104 \mathrm{IU} / \mathrm{l}$ (15 KA units). The concentration of bilirubin and transaminase activities remained normal throughout.

\section{Comment}

This patient developed acute renal failure and raised serum alkaline phosphatase activity on two occasions when exposed to cimetidine. No other drug or aetiological agent could be implicated. Cimetidine increases the serum creatinine concentration in normal people but this usually remains within the normal range. ${ }^{4}$ The mechanism is thought to be competitive inhibition of creatinine secretion in the tubules. Acute drug-induced interstitial nephritis, however, is generally considered to be a hypersensitivity response. Immunofluorescent studies usually have negative results and dense deposits are absent on electron microscopy, suggesting that this is not an antibody-mediated reaction. ${ }^{5}$ It may be an example of delayed hypersensitivity, which might explain the rise in alkaline phosphatase in our patient.

We thank Dr A M Lessells, consultant pathologist, for reporting the histological findings of the renal biopsy specimen and providing the photomicrograph.

1 Seidelin R. Cimetidine and renal failure. Postgrad Med 7 1980;56:440-1

2 Richman AV, Narayan JL, Hirschfield JS. Acute interstitial nephritis and acute renal failure associated with cimetidine therapy. Am $\mathcal{F}$ Med 1981 ; $70: 1272-4$.

3 Burland WL. Evidence for the safety of cimetidine in the treatment of peptic ulcer disease. In: Proceedings of an international symposium of histamine $\mathrm{H}_{2}$-receptor antagonists. Amsterdam, Gottingen: Excerpta Medica, 1978.

4 Haggie SJ, Fermont DC, Wyllie JH. Treatment of duodenal ulcer with cimetidine. Lancet 1976; ;:983-4.

Linton AL, Clark WF, Driedger AA, Turnbull DI, Lindsay RM. Acute interstitial nephritis due to drugs. Ann Intern Med 1980;93:735-41.

(Accepted 16 April 1982)

University Hospital of South Manchester, Manchester M20 8LR C R PAYNE, MB, MRCP, senior medical registrar

P ACKRILL, MB, FRCP, consultant nephrologist

A J RALSTON, MB, FRCP, consultant physician 